\title{
BH3-Interacting Domain Death Agonist
}

National Cancer Institute

\section{Source}

National Cancer Institute. BH3-Interacting Domain Death Agonist. NCI Thesaurus. Code C21199.

BH3-interacting domain death agonist (195 aa, $22 \mathrm{kDa}$ ) is encoded by the human BID gene. This protein plays a role in the promotion of apoptosis. 